О. В. Прохорова

\title{
МЕТОДОЛОГІЧНІ ЗАСАДИ ІНТЕНСИВНОГО НАВЧАННЯ УСНОГО ПРОФЕСІЙНОГО МОВЛЕННЯ СТУДЕНТІВ ФАКУЛЬТЕТУ ХОРЕОГРАФІЧНОЇ ОСВІТИ
}

Прохорова О. В. Методологічні засади інтенсивного навчання усного професійного мовлення студентів факультету хореографічної освіти

У статті досліджено методичні основи інтенсивного навчання усного професійного мовлення й особливості формування англомовної лінгвістичної компетенції студентів хореографічного факультету. Обгрунтовано доцільність адаптації принципів комунікативно-когнітивного підходу до умов навчання майбутніх хореографів до умов навчання англійської мови професійного спілкування та визначено ключові методичні принципи формування англомовної лінгвістичної мовної компетенції студентів. Розглянуто сучасні технології у викладанні англійської мови у вищій школі.

Ключові слова: методичні особливості, англомовна лінгвістична компетенція в усному мовленні, студенти-хореографи, принципи навчання

등. В. Прохорова, 2016. 
Прохорова О. В. Методологические основы интенсивного обучения устной профессиональной речи студентов факультета хореографического образования

В статье исследуются методические основы интенсивного обучения устной профессиональной речи и особенности формирования англоязычной лингвистической компетенции студентов хореографического факультета. Обоснована целесообразность адаптации принципов коммуникативно-когнитивного подхода к условиям обучения будущих хореографов к условиям обучения английскому языку профессионального общения и определены ключевые методические принципы формирования англоязычной лингвистической устноречевой компетенции студентов. Рассматриваются современные технологии в преподавании английского языка в высшей школе.

Ключевые слова: методические особенности, англоязычная лингвистическая компетенция в устной речи, студенты-хореографы, принципы обучения

Prokhorova O. V. Methodological principles of intensive training in oral professional broadcasting students of choreographic education

The paper is devoted to the methodological foundations of intensive training in oral professional speech and peculiarities of forming English language competence of students of choreographic faculty. The expediency of adaptation of principles of communicativecognitive approach to the learning environment of future choreographers to the conditions of teaching English for professional communication and identifies the methodological principles of forming English language linguistic competence of students. Considered a modern technology in teaching English in high school.

Modern technology in education this professionally-oriented foreign language teaching, project work in teaching, application of information and telecommunication technologies, work with computer training programs in foreign languages (multimedia system), e-learning technologies in teaching foreign languages, creating presentations in PowerPoint, using Internet resources, learning foreign language in a computer environment (forums, blogs, e-mail), newest testing technologies (the creation of a Bank of diagnostic materials in the course of academic subject «Foreign language» for computer-based testing to control students).

Methodical peculiarities of forming English language linguistic competence in oral speech of students of choreographic faculty due to the adaptation of the principles of communicative-cognitive approach to the learning environment of English for professional communication. The paper shows the methodical features, which include: the perspective of the needs of the communicative activity of the future choreographers; multi-level approach to teaching oral speech; adherence to the principles of interdisciplinarity.

Methodical features of formation of linguistic competence in English speech of students of choreographic faculty due to the adaptation of the principles of cognitivecommunicative approach to English learning environment for professional communication. Identified methodological features, including: consideration of future needs of communication of future choreographers; build a course around the subject matter and pragmatic-communicative functions of professional communication; multi-tiered approach to the study of speech; adherence to the principles of interdisciplinarity, intensive use of background knowledge, development and improvement of all aspects of secondary verbal 
identity, authenticity, interactivity, contextual conditioning, cognitive gap.

Key words: methodical peculiarities of the English linguistic competence in oral speech, the students of the choreography, the principles of teaching.

Створення передумов для входження освіти України до єдиного європейського та світового освітнього й наукового простору через упровадження в систему вищої освіти України основних ідей, сформульованих Болонською декларацією, актуалізує проблему навчання іноземних мов у системі вищої освіти. Іноземна мова сьогодні є не просто частиною культури певної нації, але й запорукою успіху, майбутньої вдалої кар'єри. Викладачеві важливо знати новітні методи викладання іноземної мови, спеціальні навчальні техніки та прийоми, щоб оптимально підібрати той чи той метод викладання відповідно до рівня знань, потреб, інтересів студентів. Адже методи навчання не $\epsilon$ якимись простими «алгоритмізованими одиницями», їх раціональне та вмотивоване використання на заняттях іноземної мови вимагає креативного підходу з боку викладача, бо педагогіка $є$ наукою й мистецтвом одночасно, тому і підхід до вибору методів навчання має грунтуватися на творчості педагога.

Цією проблемою займалося чимало фахівців. У дослідженнях обгрунтована необхідність переорієнтації кінцевої мети оволодіння мовою 3 гносеологічного аспекту на комунікативно-прагматичний (А. Богуш), вузькопрофільної спеціалізації при формуванні англомовної лінгвістичної компетенції (Н. Ізорія, С. Кіржнер, О. Шевченко); пропонуються моделі формування окремих компонентів англомовної лінгвістичної компетенції (В. Борщовецька, Н. Босак, О. Вовк, А. Кириченко, О. Лаврова, В. Осідак, Ю. Семенчук, В. Шмідт), засоби інтенсифікації іiі формування (Н. Аршинова, Я. Булахова, О. Каменський, І. Чирва, Н. Ягельська); розробляються новітні технології навчання професійного усного мовлення (О. Артем’єва, Т. Асламова, 3. Корнєва, М. Макєєва, J. Cummins, M. Swain), створюються спеціальні системи вправ для іншомовного монологічного мовлення (Н. Драб, І. Федорова).

Мета статті полягає у визначенні методичних особливостей формування англомовної лінгвістичної компетенції в усному мовленні 
студентів хореографічного факультету.

Уважаємо за необхідне навести деякі уточнення щодо термінологічних одиниць, необхідних для запропонованого дослідження. Варто, по-перше, окреслити поле використання терміна «інтенсивні методи». Його функціонування передбачає, що методи бувають і «неінтенсивні», відповідно, є небезпека змішування термінів «інтенсивний» та «ефективний». У такому разі підтримуємо думку О. Леонтьєва про два аспекти цього поняття - психологічний і методичний [7, с. 146]. Збіг значень ефективності й інтенсивності наявний лише у психологічному аспекті. Маючи змогу викладати мову інтенсивно, немає сенсу робити це екстенсивно. При такому протиставленні в семантиці слова «інтенсивний» наявна позитивна оцінка. Але в методичному аспекті інтенсивність має таке ж значення, як і традиційне, неінтенсивне навчання. Перевага надається тим чи тим методам залежно від умов і завдань навчання. Крім того, теоретичний і практичний інтерес становить визначення доцільності й ефективності як окремих інтенсивних методів, так і поєднання різних методів навчання. Завершуючи термінологічні уточнення, згадаємо ще один термін, що має стосунок як до інтенсивних, так і до традиційних методів. Мова йде про інтенсифікацію навчання.

Інтенсифікацію визначають як виконання більшого обсягу навчальної діяльності за певний час, засвоєння максимальної кількості навчальної інформації на максимально якісному рівні з найменшими витратами енергії та в мінімальні терміни. Отже, інтенсифікація діяльність, спрямована на підвищення рівня інтенсивності. Інтенсифікувати навчальний процес означає збільшити кількість засвоюваного матеріалу, забезпечити якість засвоєння, досягти високого рівня научуваності, максимальної ефективності навчання. У методиці інтенсивне навчання сформувалося як специфічна система, яка за певними параметрами відрізняється від традиційних методів викладання іноземних мов. Під інтенсивним навчанням іноземної (і нерідної) мови розуміють навчання, спрямоване

๑) О. В. Прохорова, 2016. 
здебільшого на оволодіння усним мовленням та аудіюванням. Інтенсивне навчання спирається на резерви особистості, що зазвичай не використовуються в навчальному процесі. Важливою характеристикою інтенсивних методів є стислі терміни навчання та велика щоденна концентрація навчальних годин.

У вищому навчальному закладі мета навчання іноземної мови визначається як «... формування необхідної комунікативної здатності у сферах професійного й ситуативного спілкування в усній і письмовій формах» [9, с. 23]. Державний освітній стандарт вищої професійної освіти і Програма 3 англійської мови для професійного спілкування вимагають скерованості навчання на реалізацію завдань перспективної діяльності випускників, що зумовлює пріоритет професійно зорієнтованого підходу до навчання студентів нефілологічних спеціальностей іноземних мов. Беручи до уваги природу засвоєння іноземної мови й регламентований нею характер навчання (М. Вятютнєв, А. Зернецька, J. Richards), визначимо професійно зорієнтований підхід як модифікацію комунікативно-діяльнісного підходу в умовах навчання іноземної мови. Чільним принципом комунікативно-діяльнісного підходу до навчання іноземних мов $\epsilon$ врахування перспективних потреб комунікативної діяльності учнів. Комунікативні потреби тих, хто навчається, - категорія соціальна і характеризується соціально зумовленою динамікою.

Задовго до оформлення методики викладання англійської мови зі спеціальною метою (ESP) в окрему лінгводидактичну дисципліну спостерігався попит на навчання так званої «ділової англійської мови», який A. Howatt i H. Widdowson [13, с. 257] датують 1553 роком. Основним змістом навчання ділової англійської мови були вміння читання й письма, необхідні для здійснення ділового листування, що відображало як соціальне замовлення, так і теоретикопрактичний стан лінгводидактики загалом. Із початком науковотехнічної й економічної експансії в міжнародному масштабі після другої світової війни виник попит на фахівців, які володіють мовою 
міжнародного спілкування, що слугувало стимулом пошуку нового дидактичного підходу до швидкого навчання дорослих англійської мови. Продуктивності лінгводидактичних досліджень того часу сприяло зміщення дослідницького фокусу прикладної лінгвістики 3 системи мови на динаміку реальної комунікації (M. Breen, M. Canale, M. Swain, K. Johnson, K. Morrow, H. Widdowson). Виокремленню методики викладання англійської мови зі спеціальною метою (ESP) у самостійну галузь англістики сприяв розвиток психології навчання та формування особистісно-діяльнісного підходу до навчання іноземних мов (О. Лєонтьєв, С. Рубінштейн, D. Brandes, D. Nunan).

H. Widdowson підсумував лінгвістичну й лінгводидактичну специфіку методики викладання англійської мови зі спеціальною метою так: «... опис певної сфери мови й потім використання цього опису як специфікації курсу для забезпечення тих, кого навчають, необхідно обмеженою компетенцією в цій певній сфері» [16, с. 10].

Практичним результатом стала поява підручників англійської мови для студентів-медиків, інженерів, економістів, зміст яких характеризувався насиченістю спеціалізованим вокабуляром i відображав двоетапний підхід до навчання: загальна англійська мова (General / Mainstream English) і професійно зорієнтована англійська мова (English for Professional / Occupational Purposes). Цей етап характеризувався спрямованістю навчання на оволодіння вміннями читання текстів за фахом. Аналогічна тенденція простежується й у вітчизняних теоретичних дослідженнях проблеми навчання іноземної мови студентів нефілологічних спеціальностей, у центрі уваги яких знаходилися питання наступності між вищою й середньою школою, відбору лексичного мінімуму, виявлення лінгвістичних особливостей спеціалізованих текстів.

Спрямованість навчальних посібників 3 англійської мови того часу можна охарактеризувати як оволодіння спеціалізованою макромовою спеціальності на основі адаптованих текстів, методи навчання - як свідомо-практичний (Б. Бєляєв) і свідомо-зіставний 
(Й. Берман). Наприкінці 1960-х років зросла освітня значущість для студентів нефілологічних спеціальностей дисципліни «Іноземна мова», що почала сприйматися як засіб формування професійної спрямованості особистості. Розширився зміст поняття «професійна зорієнтованість навчання іноземних мов», до якого увійшли розвиток умінь усного мовлення відповідно до ситуацій професійного спілкування і забезпечення професійної зорієнтованості не тільки предметного змісту навчання, але й діяльності 3 його засвоєння $[10$, c. 4]. Проблема координації навчання іноземної мови з навчанням профільних дисциплін конструктивно розроблялася Г. Паріковою $[9$, с. 22], О. Тарнопольським [11, с. 163], що відкидали можливість вивчення спеціального матеріалу іноземною мовою до того, як студенти опанують зміст профільних дисциплін, обгрунтовували субординацію між іншомовною професійно-комунікативною компетенцією та відповідною їй у рідній мові.

В останній чверті XX ст. розвиток методики викладання професійно зорієнтованої англійської мови зумовлювався ствердженням комунікативного підходу в загальній лінгводидактиці (М. Вятютнєв, П. Гурвич, І. Зимня, Г. Китайгородська, Ю. Пассов, В. Скалкін, Е. Шубін, К. Brandl, M. Breen, C. Brumfit, M. Canale, D. Hymes, W. Littlewood, інші).

Комунікативний підхід збагатив лінгводидактику розробкою структури й змісту комунікативної компетенції як мети навчання, визначенням рівнів комунікативної компетенції, долучив до сфери лінгводидактики дослідження лінгвістики дискурсу, прагматики мовлення, соціокультурного й лінгвокраїнознавчого аспектів мовних i мовленнєвих одиниць, наблизив умови навчальної мовленнєвої взаємодії тих, хто навчається, до автентичної міжкультурної ситуації. Методологічна основа комунікативного підходу послідовно висвітлена в дослідженнях Ю. Пассова [8, с. 59], який розробив принципи «комунікативного методу» (дефініція автора) навчання іноземних мов, що набули статусу аксіоматичних у радянській i 
пострадянській лінгводидактиці: комунікативної спрямованості навчання; розумово-мовленнєвої активності; індивідуалізації навчання; функціональності; ситуативності, новизни чи евристичності. У теорії й практиці викладання іноземних мов комунікативний підхід мав безліч лінгводидактичних реалізацій, адаптованих до специфічних завдань методики викладання професійно зорієнтованої англійської мови (М. Finocchiaro, C. Brumfit, K. Johnsoni, K. Morrow, D. Wilkins).

Спеціалізовані курси англійської мови почали орієнтуватися на типові комунікативні функції професійного дискурсу й засоби їхньої вербалізації, що зробило їх більш економними й доступними для тих, хто навчається. Найбільшого поширення в англомовних країнах набуло навчання через зміст (D. Brinton, M. Snow, M. Wesche), що розглядалося як «... логічний розвиток деяких ключових принципів комунікативного підходу до навчання мов» [5, с. 158].

Суть принципу значущості навчальної інформації полягає в опорі навчальної діяльності на особистісно значущий мовний i мовленнєвий матеріал. У навчанні через зміст відбилися концептуальні положення методики викладання англійської мови зі спеціальною метою, описані T. Dudley-Evans i M. St John [12, с. 18]: зміст навчання визначається специфічними потребами певної категорії студентів; методи й прийоми навчання суголосні зі способами діяльності, які формуються у процесі вивчення спеціалізованих дисциплін; мовленнєві вміння, типи дискурсів і жанрів мовленнєвого матеріалу відбираються за критерієм відповідності перспективній професійно-комунікативній діяльності.

Отже, у руслі комунікативного підходу принцип урахування потреб тих, кого навчають, став трактуватися як побудова навчального курсу навколо предметного змісту професійного спілкування. Англійська мова зі спеціальною метою була поділена на англійську академічну (English for Academic Purposes - EAP) та англійську професійну (English for Occupational Purposes - EOP). M. St John 
$[15$, c. 10] запропонувала розрізняти загальну англійську мову для ділового спілкування (English for General Business Purposes) i спеціалізовану англійську для ділового спілкування (English for Specific Business Purposes) для визначення змісту навчання. Аналогічна тенденція специфікації професійно зорієнтованої англійської мови спостерігається й у пострадянському освітньому просторі.

Незважаючи на численні обгрунтування необхідності вузькопрофільної спеціалізації вивчення англійської мови (Я. Булахова, Н. Ізорія, К. Маркарян, І. Томарьова), іiі доречність ставиться під сумнів окремими лінгводидактами на підставі аналізу специфіки розумово-мовленнєвих дій в окремих підсферах і підмовах (О. Митрофанова) та метатемного аналізу навчально-професійної сфери спілкування (Д. Ізаренков).

Дійсно, визначення списку метатем, сукупність яких могла б забезпечити студентів інваріантом предметної інформації, достатньої для формування іншомовної предметної компетенції фахівців низки спеціальностей одного профілю, уявляється можливим і доцільним. 3 іншого боку, комунікативна стратегія усномовленнєвої взаємодії більшою мірою визначається специфікою професійного дискурсу й інституціональним статусом комунікантів.

Сьогодні відбувається реформування навчального процесу у вишах України згідно з загальноєвропейськими вимогами до якості освіти: інформатизація освітнього простору, інтеграційні процеси в сучасній вітчизняній освіті, налагодження українськими навчальними закладами співпраці з європейським у сфері навчальної та наукової діяльності, студентські міжнародні обміни, можливість здобуття другої вищої освіти та навчання за магістерськими програмами за кордоном. В умовах реформування вищої школи мають змінюватися також і освітні технології викладання іноземних мов.

Метою навчання іноземної мови у вищій школі на сучасному етапі є оволодіння студентами комунікативними компетенціями, що дасть змогу реалізувати їхні знання, уміння, навички для розв'язання 
конкретних комунікативних завдань у реальних життєвих ситуаціях. Завдяки розвитку нових технологій можемо говорити про поступовий перехід навчання іноземних мов на новий рівень, який забезпечується насамперед новими методами й засобами навчання. Нові інформаційні технології впливають на всі компоненти системи навчання: мету, зміст, методи й організаційні форми навчання, засоби навчання, що уможливлює розв'язання складних та актуальних завдань педагогіки, а саме: розвиток інтелектуального, творчого потенціалу, аналітичного мислення й самостійності того, хто навчається. Ці технології у викладанні іноземних мов пов'язані як із радикальною зміною методичної парадигми, так і з технічним і технологічним оновленням процесу навчання, що виражається в масовому застосуванні нових засобів навчання - перш за все мультимедійних комп'ютерних програм, які отримали поширення в навчальному процесі. Якісна мовна підготовка студентів не можлива без використання сучасних освітніх технологій.

Сучасні технології в освіті - це професійно зорієнтоване навчання іноземної мови, проектна робота в навчанні, застосування інформаційних i телекомунікаційних технологій, робота 3 навчальними комп'ютерними програмами 3 іноземних мов (система мультимедіа), дистанційні технології в навчанні іноземних мов, створення презентацій у програмі Power Point, використання інтернетресурсів, навчання іноземної мови в комп'ютерному середовищі (форуми, блоги, електронна пошта), новітні тестові технології (створення банка діагностичних матеріалів 3 курсу навчального предмета «Іноземна мова» для проведення комп'ютерного тестування задля контролю ЗУН студентів).

Комп'ютеризація навчання іноземної мови допомагає: a) скоротити час на вивчення мови і полегшити доступ до інформації; б) постійно оновлювати навчальний матеріал; в) формувати обсяг та складність інформації відповідно до мети заняття та рівня підготовленості студентів; г) ознайомлювати користувачів із великою 
кількістю матеріалу лінгвокраїнознавчого характеру, беручи до уваги й елементи культур інших країн і народів.

Ученими доведено, що застосування мультимедійних матеріалів і комп'ютерних мереж скорочує час навчання майже втричі, а рівень запам'ятовування через одночасне використання зображень, звуку, тексту зростає на $30-40 \%$.

Крім того, комп'ютер є одним із засобів підвищення мотивації студентів. Мотивування студентів до вивчення іноземних мов в умовах глобалізації помітно спростилося, але саме інтернет дає змогу пересвідчитися в розмаїтті сучасного світу, у легкості та зручності пошуку знань і постійного зв'язку з довкіллям.

Отже, використання сучасних технологій навчання в оволодінні іноземною мовою сприятиме як вдосконаленню процесу формування іншомовної комунікативної компетенції, так i розвитку інтелектуальних здібностей, набуття особистісно значущих для кожного знань і вмінь.

Методичні особливості формування англомовної лінгвістичної компетенції в усному мовленні студентів хореографічного факультету зумовлені адаптацією принципів комунікативно-когнітивного підходу до умов навчання англійської мови професійного спілкування. Виявлені методичні особливості, що передбачають: урахування перспективних потреб комунікативної діяльності майбутніх хореографів; побудову навчального курсу навколо предметного змісту і прагматично-комунікативних функцій професійного спілкування; рівневий багатоступінчастий підхід до навчання усного мовлення; дотримання принципів міждисциплінарності, інтенсивного застосування фонових знань, розвитку й удосконалення всіх сторін вторинної мовленнєвої особистості, автентичності, інтерактивності, контекстуальної зумовленості, когнітивного розриву.

\section{Література}

1. Артемьева О. А. Система учебно-ролевых игр профессиональной направленности : [монография] / О. А. Артемьева, М. Н. Макеева. - Тамбов : Изд-во ТГУ, 2007. - 208 с. () О. В. Прохорова, 2016. 
2. Асламова Т. В. Интерактивная модель обучения устному иноязычному общению в неязыковом вузе / Т. В. Асламова // Вестник Моск. гос. лингвист. ун-та. М. : Изд-во МГЛУ, 2002. - Вып. 467. - С. 48-61.

3. Вербицкий А. А. Активное обучение в высшей школе : контекстный подход : [метод. пособие] / А. А. Вербицкий. - М. : Высшая школа, 1991. - 207 с.

4. Григорьева В. С. Элементы теории и практики делового дискурса на материале немецкого и русского языков : [учебное пособие] / В. С. Григорьева, М. К. Любимова. - Тамбов : Изд-во ТГТУ, 2006. - 80 с.

5. Каменская И. Б. Методические особенности формирования англоязычной лингвистической компетенции в устной речи будущих менеджеров / И. Б. Каменская // Ученые записки Таврического национального университета им. В. И. Вернадского. Серия : Проблемы педагогики средней и высшей школы. - 2013. - Т.25 (65). - №1. С. 177-191.

6. Корнєва 3. М. Методика навчання майбутніх економістів англійського ділового мовлення на основі технології занурення : дис. ... канд. пед. наук /3. М. Корнєва. - К., 2006. - $304 \mathrm{c}$.

7. Леонтьев А. А. Принцип коммуникативности и психологические основы интенсификации обучения иностранным языкам / А. А. Леонтьев // Язык и культура в филологическом вузе. - М., 2006. - С. 145-155.

8. Пассов Е. И. Коммуникативный метод обучения иноязычному говорению : [науч. изд.] / Е. И. Пассов. - [2-е изд.]. - М. : Просвещение, 1991. - 222 с.

9. Парикова Г. В. Исследование возможностей повышения эффективности процесса обучения иностранным языкам в неязыковом вузе / Г. В. Парикова. - Л. : Изд-во Ленингр. ун-та, 1972. - 44 с.

10. Програма 3 англійської мови для професійного спілкування = English for Specific Purposes (ESP) National Curriculum for Universities / [кол. авторів : Г. Є. Бакаєва, О. А. Борисенко, І. І. Зуєнок та ін.]. - К. : Ленвіт, 2005. - 119 с.

11. Рощина Е. В. Функции иностранного языка как учебного предмета в системе обучения в университете / Е. В. Рощина // Иностранный язык на неспециальных факультетах : [межвуз. сб.]. - Вып. 1. - Л. : Изд-во ЛГУ, 1978. - С. 3-6.

12. Тарнопольский О. Б. Методика обучения английскому языку для делового общения : [учебное пособие] / О. Б. Тарнопольский, С. П. Кожушко. - К. : Ленвіт, 2004. - 192 c.

13. Dudley-Evans T. Developments in English for Specific Purposes : A MultiDisciplinary Approach / T. Dudley-Evans, M.J. St John. - Cambridge : CUP, 1998. - 301 p.

14. Howatt A. P. R. A History of English Language Teaching / A. P. R. Howatt, H. G. Widdowson. - [2nd ed.]. - OUP, 2004. - 417 p. - (Oxford Applied Linguistics).

15. Richards J. C. Approaches and Methods in Language Teaching / J. C. Richards, T. S. Rodgers. - [2nd ed.]. - CUP, 2005. - 279 p. - (Cambridge Language Teaching Library).

16. St John M. J. Business is Booming: Business English in the 1990s / Maggie Jo St $-303-$

(C) О. В. Прохорова, 2016. 
John // English for Specific Purposes. - 1996. - Vol. 15. - No. 1. - P. 3-18.

17. Widdowson H. G. Communication and Community. The Pragmatics of ESP / H. G. Widdowson // English for Specific Purposes. - 1998. - No. 17 / 1. - P. 3-14.

Стаття надійшла до редакиї 15.06.2016 p. 